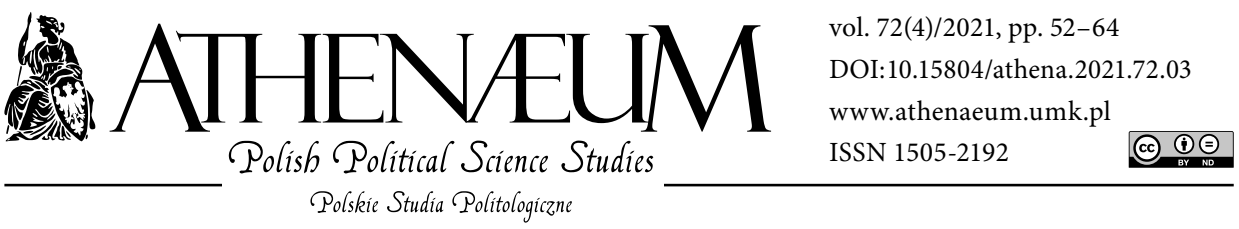

\title{
WAR AND PEACE JOURNALISM IN THE COVERAGE OF THE 2020 US PRESIDENTIAL ELECTION
}

\author{
DZIENNIKARSTWO WOJENNE I POKOJOWE W NAGŁOŚNIENIU \\ AMERYKAŃSKICH WYBORÓW PREZYDENCKICH W 2020 ROKU
}

Róża Norström*๑, Mariusz Kolczyński**๑

\section{- ABSTRACT}

This paper aims at empirically testing the usefulness of Galtung's model of peace and war journalism in the analysis of the coverage of the 2020 US presidential election by Polish television news programs. The work also aims to investigate whether similar mechanisms can be used in the coverage of elections as in the coverage of wars. We explore through what perspective - peace or war journalism - the election was covered and what specific mechanisms of these models were used. We also discuss whether the war journalism or peace journalism coverage perspective of the event was influenced by polarization and the political affiliation of the Polish media and how these factors influenced the way the US presidential candidates were presented.

Keywords: war journalism; peace journalism; presidential election; television news; coverage
Celem niniejszego artykułu jest empiryczne sprawdzenie przydatności modelu dziennikarstwa pokojowego i wojennego Galtunga w analizie relacjonowania amerykańskich wyborów prezydenckich z 2020 roku przez polskie telewizyjne programy informacyjne. Praca ma również na celu zbadanie, czy w relacjonowaniu wyborów mogą być stosowane mechanizmy podobne do tych wykorzystywanych przy relacjach wojennych. W artykule badamy, za pomocą jakiej perspektywy - dziennikarstwa pokojowego czy dziennikarstwa wojennego - były relacjonowane wybory i jakich specyficznych mechanizmów z tych modeli użyto. Dyskutujemy również, czy na perspektywę relacjonowania wydarzenia przez pryzmat dziennikarstwa wojennego lub dziennikarstwa pokojowego wpłynęła polaryzacja i polityczna przynależność polskich mediów i jak te czynniki warunkowały sposób ukazywania kandydatów na prezydenta USA.

Słowa kluczowe: dziennikarstwo wojenne; dziennikarstwo pokojowe; wybory prezydenckie; wiadomości telewizyjne; relacjonowanie

* University of Silesia in Katowice, Institute of Journalism and Media Communication.

** University of Silesia in Katowice, Institute of Journalism and Media Communication. 


\section{INTRODUCTION}

War and peace journalism (hereinafter abbreviated as WJ and PJ, respectively) research focuses on media image of wars and armed conflicts. These concepts can also be used to analyze presidential elections. Due to the conflictual character of presidential elections and its usually high polarization, as in the case of the 2020 US presidential election (Bitecofer, 2020), similar mechanisms can be used in the coverage of this phenomenon, as in the coverage of wars. According to Galtung (2006), television, which is still the leading medium for covering elections (Farnsworth \& Lichter, 2011), may favor the WJ perspective. On the other hand, if an election takes place in a foreign country - from the perspective of the media in question - it can favor the PJ perspective. However, coverage of foreign events by national media may also be biased, and this can affect the domination of a WJ or PJ mode in news.

The purpose of this article is to test the usefulness of a WJ and PJ perspective in the analysis of the US election coverage. Based on the Polish case, we explore through what perspective - WJ or PJ - the election was covered in television, and what specific mechanisms of Galtung's model (2006) were used. We also discuss whether the politicization and polarization of the Polish media (DobekOstrowska, 2019) influenced how the election and candidates were covered, from the perspective of WJ and PJ. The political climate in a given country and the degree of media politicization and diversity of opinion influence foreign events coverage, and whether it is biased or not (Bläsi, 2004). The study seeks answers to the following questions:

1. Through what perspective - WJ or PJ - was the 2020 US presidential election covered?

2. What specific mechanisms of WJ and PJ were used in the coverage?

\section{METHODOLOGY}

To answer the research questions, content analysis with elements of framing analysis and comparative analysis of three nationwide TV news programs "Wiadomości" on TVP, "Fakty" on TVN and "Wydarzenia" on Polsat was conducted. We chose these media because they differ in terms of editorial policy, politicization and ownership. TVP is a public service medium influenced by the ruling party Law and Justice (PiS), and TVN and TVP are privately owned 
(Pokorna-Ignatowicz, 2013). While TVN expresses conditional support for opposition parties (e.g., Civic Coalition), Polsat is considered politically neutral (Seklecka, 2017). The political diversity of these media may mean that they used different coverage perspectives of the election (PJ or WJ) and portrayed the candidates for the presidency differently.

We analyzed materials about the US election broadcasted from October 25 (a week before the election) to November 20,2020. The end point of the analysis was chosen due to the long process of counting votes and controversy surrounding the legality of the election. Each research unit was a story relating to the election presented in a broadcast. Several research units could be taken from a single broadcast, and each of them were examined. The analysis was carried out by two coders who examined the research units using a codebook consisting of 28 single-choice and multiple-choice questions as well as open-ended questions. We focused, e.g., on which candidate was presented as the winner of the election or what consequences of the election was discussed. We conducted an intercoder reliability test on a random sample of six research units ( $10 \%$ of all materials), excluding open-ended questions. Agreement was measured in percentage, which is a common method of reporting the degree to which coders agree (Feng, 2014). The results show that our agreement rate was sufficient and was over $80 \%$ for the 23 categories we tested.

\section{WAR AND PEACE JOURNALISM - CHARACTERISTIC FEATURES AND PREMISES}

In the 1970s, Galtung (2006) developed PJ as an alternative to the dominating war-oriented approach of the mainstream media. He identified two modes of journalism - WJ and PJ, which he described as two ways of presenting an event involving conflict. Each of these two modes is defined based on four dichotomous variables (Table 1) which can contribute to either an escalation or de-escalation of the covered conflict.

Galtung's classification highlights the importance of the language of the news and journalistic practice (Lynch \& McGoldrick, 2005). Demonization and dehumanization are mechanisms used in WJ to construct "enemy images" of actors and emphasize the antagonism between "us" and "them" (Wolsfeld, 2004). This division and focusing on the aggressive actions of one part can make the violence be presented through situational or dispositional enemy images 
Table 1. Galtung's Characteristics of War and Peace Journalism

\begin{tabular}{|c|l|}
\hline \multicolumn{1}{|c|}{ PJ } & \multicolumn{1}{|c|}{ Weace/conflict-oriented } \\
\hline \multicolumn{1}{|c|}{ WJ } \\
\hline $\begin{array}{l}\text { Defining war as a problem; exploring conflict's } \\
\text { context; humanizing actors }\end{array}$ & $\begin{array}{l}\text { Presenting war as a zero-sum game; using "us- } \\
\text {-them" rhetoric and dehumanizing "them"; omitting } \\
\text { the wider context of the conflict }\end{array}$ \\
\hline People-oriented & \multicolumn{1}{|c|}{ Propaganda-oriented } \\
\hline Exposing untruths on all sides & $\begin{array}{l}\text { Exposing "their" lies and minimizing the guilt of } \\
\text { "our" side }\end{array}$ \\
\hline $\begin{array}{l}\text { Taking into account opinions of all sides and actors; } \\
\text { focusing on suffering all over }\end{array}$ & $\begin{array}{l}\text { Presenting elite voices and emphasizing "our" } \\
\text { suffering }\end{array}$ \\
\hline \multicolumn{1}{|c|}{ Soled } & \multicolumn{1}{|c|}{ Victory-oriented } \\
\hline $\begin{array}{l}\text { Focusing on solution rather than on how to win; } \\
\text { promoting peace initiatives as a way to resolve the } \\
\text { dispute }\end{array}$ & $\begin{array}{l}\text { Stressing the achievement of victory through } \\
\text { violence and perceiving victory over the "enemy" as } \\
\text { the final goal }\end{array}$ \\
\hline
\end{tabular}

Source: Galtung (2006).

(Ottosen, 1995). In the first case, the actual aggressive actions are presented, while in the second the media create expectations based on stereotypes and prejudices for an actor to use violence. "Us" and "them" can also be reinforced by victimization. The coverage of the suffering of one side and the use of victimizing language indicates that this is the "worthy" victim (Herman \& Chomsky, 1988) who deserves the sympathy. The emotionalization of language through demonization and victimization is contrary to PJ, which aims to frame stories in a more comprehensive way.

Journalistic practice, i.e., the selection of subjects and framing of actors (Entman, 1993), which influences how the audience perceives and understands given events (Gans, 1979), is another important element of Galtung's classification. Lynch and McGoldrick (2005) expanded Galtung's model with 17 good journalistic practices, i.a.: searching for common ground; disaggregating the "us" and "them"; avoiding demonizing words. News sourcing practices seem particularly important. The elite-oriented news sourcing of WJ makes the narrative of politicians dominant and imposes an interpretation of events in accordance with their interests (Fong \& Gek Koon, 2019). PJ takes into account the arguments of both parties and the opinions of common people, who are often victims of political violence by the elite. 
The WJ or PJ perspective on foreign events might be also influenced by connections between the covering and the covered state. Implementation of PJ is easier when "our" country or "our" ally is not involved in the conflict event (Bläsi, 2004). The coverage can then be more unbiased and win-win oriented. However, political or cultural closeness between countries can make actors that are "our" allies be portrayed positively, and those defined as enemies negatively (Kempf, 2012), which is a manifestation of WJ. The use of WJ when presenting foreign events and their interpretation through national contexts can also be an element of a media strategy aimed at increasing the audience's interest in the covered phenomenon and to identify themselves with one of the parties.

\section{WAR AND PEACE JOURNALISM IN RELATION TO THE COVERAGE OF ELECTIONS}

Nowadays the average media user is becoming less able to absorb complex political content. The media responds by reducing the complexity of the news and simplifying political content. This is inconsistent with PJ, where journalists shape the message in a multifaceted way to provide recipients with sufficient knowledge about the event - e.g., by ensuring that all participants in an election process are "visible" in the media (Hyde-Clarke, 2011). In this way PJ supports democratization processes by creating "common grounds for all stakeholders as an approach to conflict resolution" (Auwal \& Ersoy, 2020, p. 19). Television coverage usually revolves around the issue of electoral victory/defeat (horse race frame), with overrepresentation of personalized strategic game frames and the interpretation of competition through conflict frames (Norris, 2000). The general trend toward negative formatting and emotionalization of election coverage (Gerstlé \& Nai, 2019) fits into the pattern of WJ by covering elections with a zero-sum orientation, emphasizing the division into "us" and "them", or using demonizing language.

The dominance of the WJ perspective through the progressive polarization of news content (Van Aelst et al., 2017) often manifests in biased selection and making content to appeal to the segments of the audience that share the values displayed by the media. The classic approach to conflict frames (Semetko \& Valkenburg, 2000), with high exposure of conflicts between individuals or groups, and focusing content around disagreement rather than consensus reflects the way election campaigns are reported by mainstream media today. Conflict 
frames help to simplify the electoral rivalry, often reducing it to a personal conflict between candidates or party leaders. The use of personal conflict frames allows to create a message that does not require knowledge about current events and stimulates people's emotions. In this context, attention should be paid to three aspects of media coverage: the method of selecting information, how the information is given exposure (Scheufele, 2000), and how issues are defined and interpreted (Entman, 1993). The media logic of television makes the speed of transferring information of primary importance in the coverage of election campaigns, and the standards of selecting information become less important. This leads to limiting the role of journalistic integrity and to the use of unverified and sometimes untrue information (the "propaganda-oriented" feature of WJ).

The sources of information that journalists rely on and their narratives influence how news are presented. In the case of political events, politicians, being the main source of news, can create their own versions of reality (Auwal \& Ersoy, 2020). Political bias in media and the relationships between media and politicians play an important role during election campaigns because journalists may influence election outcomes through their coverage. Relations between voters and politicians are usually mediated by the journalists (Haug, Koppang, \& Svennevig, 2010) and what the audience knows about the candidates and how they perceive politicians is usually taken from the media. The reactive role of the media in WJ means that what people learn from the news is a reflection of the dominant political discourse, unlike in PJ where the media offer counter-narratives that reduce the dominance of one party's opinion.

\section{RESULTS \\ "Winner" and "loser" - the presidential election as a zero-sum game}

The American two-party political system means that the president is either a representative of the Democratic or Republican party. This system can limit the "visibility" of other candidates in the media giving the election an elitist dimension.

For all the media (63\% of the materials), the winner of the election was Joe Biden, who was most often framed in this way, and his opponent as "loser of the election". The media were repeatedly calling Biden "the $46^{\text {th }}$ [US] president" 
(TVN) in advance of the final result being announced. Biden's victory was emphasized mostly by TVN, which indicate the medium's sympathy for this politician. Trump was described as the "winner" only by TVP when it referred to the president's own words. This shows the similarity between the horse race framing used to emphasize electoral victory/defeat (Aalberg, Strömbäck, \& de Vreese, 2012) and the "zero-sum orientation" of WJ (Galtung, 2006). Although other candidates also took part in the election, in the media's opinion none of them had a chance for winning and none of them received any attention, which can also be an expression of a zero-sum game orientation and an elitist dimension of the election (Hyde-Clarke, 2011).

Table 2. Candidate Presented as the Winner of the Election

\begin{tabular}{|l|c|c|c|c|c|}
\hline \multicolumn{1}{|c|}{ Category } & TVP & TVN & Polsat & Total & N = \\
\hline Donald Trump & $10 \%$ & $0 \%$ & $0 \%$ & $4 \%$ & 2 \\
\hline Joe Biden & $52 \%$ & $75 \%$ & $63 \%$ & $63 \%$ & 36 \\
\hline Other candidate & $0 \%$ & $0 \%$ & $0 \%$ & $0 \%$ & 0 \\
\hline No information & $38 \%$ & $25 \%$ & $37 \%$ & $33 \%$ & 19 \\
\hline
\end{tabular}

Source: Authors' own elaboration.

The zero-sum game orientation of election is also evident in how the media showed similarities and differences between the candidates. We found out that all the media mainly emphasized the differences between the candidates, but TVN and TVP especially, which are the media expressing support for certain political forces in Poland. These differences concerned ideological differences, describing Trump as a "conservative politician" (all media), "defender of traditional values" (TVP), or "nationalist" (TVN), while Biden was described as a "liberal/ leftist politician" (all media). For TVN, being a "liberal/leftist politician" had positive connotations, while for TVP it was something negative. In this way, the studied media gave the election a "war/violence oriented" perspective and through linguistic framing mechanisms reinforced the division into "us" and "them" (Wolsfeld, 2004). This could have affected the viewers' perception of the election negatively as being a "conflict" between two political forces, rather than as a process of strengthening democratic institutions. 


\section{"Their" untruths and illegal actions in the 2020 US presidential election process}

Almost half of the materials contained information about accusations made by the actors in the coverage and by the media of illegal activities against participants in the election process. In over $80 \%$ of the materials Biden was accused of doing something illegal. This was largely Trump and his campaign staff making statements regarding electoral rigging by the Democrats. Similar comments from the Polish journalists were less frequent. The frequent quoting of Trump, who called Biden a "cheater" (TVP and TVN) and claimed that he "stole the election" (TVN), could have nevertheless affected the viewers' image of the Democratic candidate. It is an example of the media's use of the "propaganda-oriented" and "elite-oriented" perspectives of WJ, where leaders interpret and define what issues are discussed in the news (Auwal \& Ersoy, 2020). Accusations against Trump's illegal activity appeared only in Polsat, mainly in the context of criticism against Trump's unwillingness to transfer power to his opponent.

Table 3. Actor Accused of Illegal Activity

\begin{tabular}{|l|c|c|c|c|c|}
\hline \multicolumn{1}{|c|}{ Category } & TVP & TVN & Polsat & Total & N = \\
\hline Donald Trump & $0 \%$ & $0 \%$ & $20 \%$ & $4 \%$ & 1 \\
\hline Joe Biden & $91 \%$ & $100 \%$ & $60 \%$ & $89 \%$ & 24 \\
\hline Other Democrat representative & $9 \%$ & $0 \%$ & $20 \%$ & $7 \%$ & 2 \\
\hline
\end{tabular}

Note: We only included materials where an accusation of illegal activity could be found.

Source: Authors' own elaboration.

We also found that certain actors were accused of disinformation and spreading false information. Trump was mainly attributed to spreading disinformation (Table 4). This mostly had to do with the president's posts on Twitter, where he questioned the legality of the election and accused Biden's staff of election fraud. There are some differences between the narratives of TVP and TVN in this respect. TVN was clearly critical of Trump's actions and how they could have had a negative impact on the public's perception of the election. In turn, TVP presented Trump as a "victim of the [American] mainstream media", and as being excessively censored by those media. This is an example of the media using the "propaganda-oriented" perspective and focusing on exposing the untruths and unlawful actions of only one side - "them" - while trying to minimize the guilt 
of "our" side, as well as the "elite-oriented" perspective by emphasizing only "our" suffering (Galtung, 2006).

Table 4. Actor Accused of Disinformation and Spreading False Information

\begin{tabular}{|l|c|c|c|c|c|}
\hline \multicolumn{1}{|c|}{ Category } & TVP & TVN & Polsat & Total & N = \\
\hline Donald Trump & $100 \%$ & $100 \%$ & $40 \%$ & $77 \%$ & 10 \\
\hline Joe Biden & $0 \%$ & $0 \%$ & $20 \%$ & $8 \%$ & 1 \\
\hline Other & $0 \%$ & $0 \%$ & $40 \%$ & $15 \%$ & 2 \\
\hline
\end{tabular}

Note: We only included materials where an accusation of disinformation and false information could be found.

Source: Authors' own elaboration.

\section{War or peace? Possible consequences of the election according to the media}

Connected with how the media presents the candidates of the presidential election is what they project will happen when one of the candidates win. The postelection scenario most often mentioned by the media was "nationwide protests and riots" ( $28 \%$ of the materials), which confirms that the media used similar mechanisms as in conflict reporting and focused on negative consequences of the event. All media, except Polsat, predicted this type of consequences and it mainly concerned aggressive actions by supporters of Biden and Trump. This can be associated with the "zero-sum game orientation" and the "victory-oriented" element of Galtung's (2006) WJ mode, where victory can be achieved through physical violence. Trump voters were portrayed by TVP as activists expressing their dissatisfaction with the alleged electoral fraud through protests, which can be considered as an attempt by the public service broadcaster to justify their actions, minimize their guilt ("propaganda-oriented" perspective) and recognize them as "worthy" victims (Herman \& Chomsky, 1988). This victimization could influence TVP's audience to identify with Trump and his voters through compassion, and also affect their interest in following the news. TVP often emphasized the aggressiveness of Biden's supporters, calling them "aggressive leftist brawlers", whose "victims" were Trump's voters and the president himself, which is an example of an "elite-oriented" perspective where the media emphasize the suffering of only one side and create situational and dispositional enemy images of the 
Democratic candidate and his voters (Ottosen, 1995). TVN used a more neutral language when describing both groups of voters, although it was mentioned that the election of either candidate could lead to social unrest. Polsat more often emphasized the peaceful consequences of the election, i.e., the "depolarization of society" ( $25 \%$ of the materials), which can be associated with the "solutionoriented" perspective of PJ (Galtung, 2006).

Table 5. Post-Election Scenario and Consequences of the Election

\begin{tabular}{|l|c|c|c|c|c|}
\hline \multicolumn{1}{|c|}{ Category } & TVP & TVN & Polsat & Total & N= \\
\hline No scenario & $18 \%$ & $5 \%$ & $56 \%$ & $25 \%$ & 14 \\
\hline Situation unchanged & $10 \%$ & $0 \%$ & $0 \%$ & $4 \%$ & 2 \\
\hline Nationwide protests and riots & $38 \%$ & $25 \%$ & $19 \%$ & $28 \%$ & 16 \\
\hline New order & $14 \%$ & $25 \%$ & $0 \%$ & $14 \%$ & 8 \\
\hline Deepening of the polarization of society & $10 \%$ & $5 \%$ & $0 \%$ & $5 \%$ & 3 \\
\hline Depolarization of society & $0 \%$ & $20 \%$ & $25 \%$ & $14 \%$ & 8 \\
\hline Improving US relations with the rest of the world & $5 \%$ & $10 \%$ & $0 \%$ & $5 \%$ & 3 \\
\hline $\begin{array}{l}\text { Deterioration of US relations with the rest of the } \\
\text { world }\end{array}$ & $5 \%$ & $10 \%$ & $0 \%$ & $5 \%$ & 3 \\
\hline
\end{tabular}

Source: Authors' own elaboration.

\section{CONCLUSION}

The study has shown that Galtung's model (2006) is applicable in the analysis of elections. It confirms that there are similarities between election coverage and conflict reporting, expressed in the use of similar mechanisms, e.g., focusing on elites and emotionalizing the language. Our research also shows that the type of medium influences the coverage perspective of the reported event, which confirms that television favors the WJ perspective.

Our analyses confirm Bläsi's findings (2004) about the impact of national political preferences and media politicization on the coverage of foreign events and the application of $\mathrm{WJ}$ and $\mathrm{PJ}$ in this respect. We found that the $\mathrm{WJ}$ perspective was dominant in all media, and especially in TVP and TVN - the most politicized of the broadcasters (Seklecka, 2017) - which shows that Galtung's model (2006) reflects the influence of political discourse on that sphere of the media. This study also found that WJ can be used by domestic media to simplify 
the coverage of foreign events and make it more attractive for the audience by referencing national contexts. We observed an attempt to transfer the patterns of reporting on Polish election campaigns, characterized by negative emotions, to election campaigns in other countries to make the audience interpret them similarly as domestic events. The attitudes expressed by the media toward the candidates were strongly correlated with their domestic party preferences. This correlation was used by the media to give the coverage an appropriate emotional and ethnocentric character, and facilitated the adaptation of attractive and engaging game frames and conflict frames in a zero-sum formula ("war/ violence-oriented" perspective of WJ) (Gerstlé \& Nai, 2019). The media also brought the audience closer to the event through personalization and a focus on a few highly important players. We found that by giving the coverage an elitist dimension and focusing only on the potential election winners, the Polish media under-represented the interests of certain groups (Auwal \& Ersoy, 2020), omitting the wider context of the event (Hyde-Clarke, 2011), which shows the similarities between the studied event and conflict situations in terms of journalistic practices (Lynch \& McGoldrick, 2005).

We observed a tendency to focus on violence, e.g., nationwide protests and riots ("victory-oriented" perspective of WJ) and differences between the candidates, giving the rivalry between Trump and Biden the form of a conflict in terms of values and personal attributes. This highlighted the role of the media's political affiliations and their preferred socio-political values. This study also proved that the coverage of foreign events can be biased, and that when "our" ally takes part in the reported event, the implementation of PJ is almost impossible (Kempf, 2012). The analyzed media used linguistic framing mechanisms (Entman, 1993) to position the candidates as "ours" (representing "our" values) or "theirs" (representing "their" values). This created a dichotomous - and even hostile - image of the situation in the US. The studied media constructed situational and dispositional "enemy images" of the candidates (Ottosen, 1995) and demonized and victimized them (Herman \& Chomsky, 1988), which created the impression of a deep divide in American society. This type of radically conflictual narrative was mostly visible in the coverage by the public service broadcaster - TVP. TVP's coverage is a textbook example of the "us" vs. "them" perspective of WJ (Galtung, 2006), contrasting the "defender of traditional values" - Trump - with the progressive "liberal/leftist" Biden. This image of an axiological conflict to a large extent overlapped with the Polish political conflict, creating the sense of a universal conflict of values through 
a simplified zero-sum approach. This is in line with the general trend of using socio-cultural national contexts in the interpretation of foreign news (Gans, 1979).

The apparent drive to dramatize the coverage, thus increasing its attractiveness, contributed to high media exposure of conspiracy theories about alleged election fraud. As a consequence, the traditional principles of journalistic integrity gave way to a new type of aggressive "paranoid style" of television journalism (Norris, Garnett, \& Grömping, 2020), typical for traditional media fighting to maintain its market position in a high-choice media environment. The traditional news media's adaptation of radical forms of conflict frames in reporting elections results from the need to adapt to the new network media logic, which can give the coverage the features of WJ.

\section{REFERENCES:}

Aalberg, T., Strömbäck, J., \& de Vreese, C.H. (2012). The Framing of Politics as Strategy and Game: A Review of Concepts, Operationalizations and Key Findings. Journalism, 13(2), 162-178. DOI: 10.1177/1464884911427799.

Auwal, M.A., \& Ersoy, M. (2020). Peace Journalism Strategy for Covering Online Political Discourses in a Multipolar Society and the New Public Sphere. Information Development. DOI: $10.1177 / 0266666920967056$.

Bitecofer, R.L. (2020). Polarization and Democratic Accountability in the 2020 Presidential Election. Society, 57(5), 507-510. DOI: 10.1007/s12115-020-00521-3.

Bläsi, B. (2004). Peace Journalism and the News Production Process. Conflict \& Communication Online, 3(1/2), 1-12.

Dobek-Ostrowska, B. (2019). Polish Media System in a Comparative Perspective: Media in Politics, Politics in Media. Berlin: Peter Lang.

Entman, R.M. (1993). Framing: Toward Clarification of a Fractured Paradigm. Journal of Communication, 43(4), 51-58. DOI: 10.1111/j.1460-2466.1993.tb01304.x.

Farnsworth, S.J., \& Lichter, S.R. (2011). Network Television's Coverage of the 2008 Presidential Election. American Behavioral Scientist, 55(4), 354-370. DOI: $10.1177 / 0002764211398066$.

Feng, G.C. (2014). Intercoder Reliability Indices: Disuse, Misuse, and Abuse. Quality and Quantity, 48(3), 1803-1815. DOI: 10.1007/s11135-013-9956-8.

Fong, Y.L., \& Gek Koon, J.H. (2019). The South China Sea Dispute and War/Peace Journalism: A Framing Analysis of a Malaysian Newspaper. KOME: An International Journal of Pure Communication Inquiry, 7(2), 17-36. DOI: 10.17646/ KOME.75672.32.

Galtung, J. (2006). Peace Journalism as an Ethical Challenge. Global Media Journal: Mediterranean Edition, 1(2), 1-5.

Gans, H.J. (1979). Deciding What's News: A Study of CBS Evening News, NBC Nightly News, Newsweek, and Time. New York: Pantheon Books. 
Gerstlé, J., \& Nai, A. (2019). Negativity, Emotionality and Populist Rhetoric in Election Campaign Worldwide, and Their Effects on Media Attention and Electoral Success. European Journal of Communication, 34(4), 410-444. DOI: $10.1177 / 0267323119861875$.

Haug, M.M., Koppang, H., \& Svennevig, J. (2010). Moderator Bias in Television Coverage of an Election Campaign with No Political Advertising. Nordicom Review, 31(2), 79-94. DOI: 10.1515/nor-2017-0131.

Herman, E.S., \& Chomsky, N. (1988). Manufacturing Consent: The Political Economy of the Mass Media. New York: Pantheon Books.

Hyde-Clarke, N. (2011). Political Posturing and the Need for Peace Journalism in South Africa: The Case of Julius Malema. Communicatio: South African Journal for Communication Theory and Research, 37(1), 41-55. DOI: 10.1080/02500167.2011.558018.

Kempf, W. (2012). Peace Journalism, the Israeli-Palestinian Conflict, the German Press and the German Public. Bulletin du Centre de recherche français à Jérusalem, 23, 1-14. Lynch, J., \& McGoldrick, A. (2005). Peace Journalism. Gloucestershire: Hawthorn Press. Norris, P. (2000). A Virtuous Circle: Political Communications in Postindustrial Societies. Cambridge: Cambridge University Press.

Norris, P., Garnett, H.A., \& Grömping, M. (2020). The Paranoid Style of American Elections: Explaining Perceptions of Electoral Integrity in an Age of Populism. Journal of Elections, Public Opinion and Parties, 30(1), 105-125. DOI: 10.1080/17457289.2019.1593181.

Ottosen, R. (1995). Enemy Images and the Journalistic Process. Journal of Peace Research, 32(1), 97-112. DOI: 10.1177/0022343395032001008.

Pokorna-Ignatowicz, K. (Ed.) (2013). Polski system medialny 1989-2011. Kraków: Wydawnictwo UJ.

Scheufele, D.A. (2000). Agenda-Setting, Priming, and Framing Revisited: Another Look at Cognitive Effects of Political Communication. Mass Communication \& Society, 3(2-3), 297-316. DOI: 10.1207/S15327825MCS0323_07.

Seklecka, A. (2017). „Alternatywne światy”, czyli różnice w relacjonowaniu wydarzeń w „Faktach” TVN i „Wiadomościach” TVP. Political Preferences, 16, 131-152. DOI: 10.6084/m9.figshare.5605687.

Semetko, H.A., \& Valkenburg, P.M. (2000). Framing European Politics: A Content Analysis of Press and Television News. Journal of Communication, 50(2), 93-109. DOI: 10.1111/j.1460-2466.2000.tb02843.x.

Van Aelst, P., Strömbäck, J., Aalberg, T., Esser, F., de Vreese, C., Matthes, J., Hopmann, D., Salgado, S., Hubé, N., Stępińska, A., Papathanassopoulos, S., Berganza, R., Legnante, G., Reinemann, C., Sheafer, T., \& Stanyer, J. (2017). Political Communication in a High-Choice Media Environment: A Challenge for Democracy? Annals of the International Communication Association, 41(1), 3-27. DOI: $10.1080 / 23808985.2017 .1288551$.

Wolsfeld, G. (2004). Media and the Path to Peace. Cambridge: Cambridge University Press. 